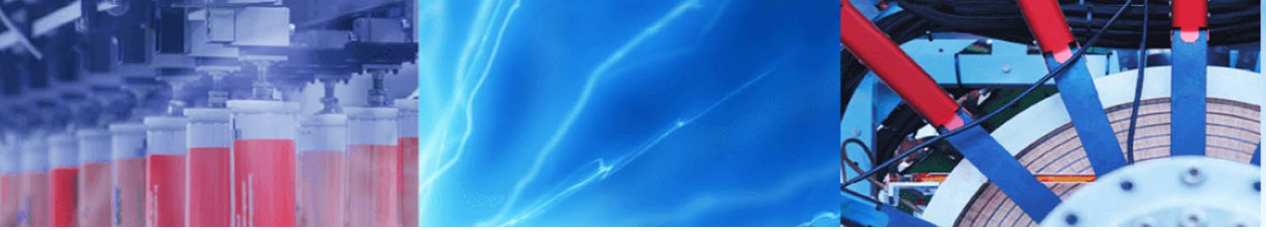

Research Article

\title{
Hydrogelogical characterization of a waste rock pile and bedrock affected by acid mine drainage from geophysical survey
}

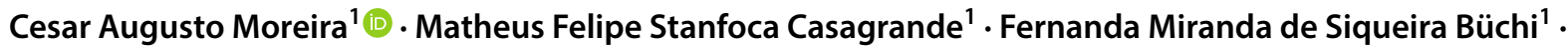 \\ Débora Andrade Targa ${ }^{1}$
}

Received: 5 April 2020 / Accepted: 9 June 2020 / Published online: 17 June 2020

(c) Springer Nature Switzerland AG 2020

\begin{abstract}
Mining activities are known for the profound changes they cause in the environment, especially those related to environmental liabilities generated by these enterprises. One major concern of this sector relies on the acid mine drainage (AMD) process, which is formed by the exposure of sulfide minerals to oxidizing conditions. As a result, the production of low-pH saline waters favors the mobilization of heavy metals to the environment. In the last decades, the characterization and monitoring of contamination plumes have become more feasible due to the application of geophysical tools, more precisely the DC resistivity geophysical method. Thus, the aim of the present study is the application of electrical resistivity tomography to understand the hydrogeological dynamic of a waste rock pile in the Osamu Utsumi uranium mine, with the identification of preferred groundwater and AMD flow. The analysis of the 2D geophysical products allowed the differentiation of high salinity water accumulation zones $(<40 \Omega \mathrm{m})$ in the interior of the pile. Likewise, the evaluation of the pseudo-3D model generated by the interpolation of 2D sections was crucial for the recognition of low resistivity zones within the bedrock, possibly controlled by fractures that work as recharge zones between the waste rock pile and the fractured aquifer. The identification of discharge and recharge zones related to the fractures system is a fundamental step for planning and actions to prevent water-sulfides interaction process, which is responsible for the generation of $A M D$, and also the installation of groundwater pumping systems.
\end{abstract}

Keywords Mining $\cdot$ AMD $\cdot$ Aquifer $\cdot$ Recharge $\cdot$ Discharge $\cdot D C$ resistivity

\section{Introduction}

The continuous population growth combined with the increase in agricultural and industrial activities is one of many factors that might contribute to the contamination of freshwater reservoirs, as a direct consequence of the generation of residues and effluents composed by a large number of substances in different concentrations. Besides, the intensive exploration and pollution of surface waters boost the demand for groundwater sources [1, 2].
Based on this context, the commitment to the preservation and monitoring of water resources has gained an important role among public opinion, especially because of their relevance for both human consumption and economic activities. Over the last decades, the concern about environmental impacts, generated by land use and human activities, leads to the creation of policies that aimed to control the quality of effluents, originating the base of water resources management [3].

Mining activities are widely known for the profound impacts they cause in the natural environment,

Cesar Augusto Moreira, moreirac@rc.unesp.br; Matheus Felipe Stanfoca Casagrande, mfs-casagrande@hotmail.com; Fernanda Miranda de Siqueira Büchi, fernandabuchi@gmail.com; Débora Andrade Targa, debora.targa@gmail.com | ${ }^{1}$ Geosciences and Exact Sciences Institute (IGCE), São Paulo State University (UNESP), Av. 24-A, 1515, Bela Vista, Rio Claro, São Paulo State 13506-900, Brazil. 
especially concerning the large mass movement necessary for their operation. Therefore, the waste material produced by ore exploration, which is characterized by concentrations below those economically viable, is disposed as piles, working as artificial porous aquifer systems [4]. Either the construction or the interaction between those waste rock piles and the natural environment consists of one of the major environmental problems related to the mining industry [5].

A very common environmental liability associated with this kind of human activity comprises the phenomenon of the acid mine drainage (AMD), whose process relies on the exposition of sulfide minerals to oxidant conditions and presence of water [6-9]. These chemical and physical parameters are very distinct from those observed in the subsurface environment, where the sulfide-containing ores were buried in chemical and physical equilibrium before the exploration procedures. As a result of this process, the generation of low-pH waters favors the mobilization of toxic chemical elements, such as heavy metals, which often occurs associated with rock matrices $[10,11]$. Considering this chemical context, the most common mineral related to AMD generation is the pyrite, whose chemical reaction is given by the following global equation (Eq. 1) [12]:

$\mathrm{FeS}_{2}+\frac{15}{4} \mathrm{O}_{2}+\frac{7}{2} \mathrm{H}_{2} \mathrm{O} \leftrightarrow \mathrm{Fe}(\mathrm{OH})_{3}+2 \mathrm{SO}_{4}^{2-}+4 \mathrm{H}^{+}$

Over the last decades, the use of geophysical methods on environmental liability studies provided an effective alternative for groundwater management, as well as on the characterization, monitoring and remediation of contaminated sites. Moreover, this tool has multiple advantages when compared to conventional direct techniques, including the possibility of fast screening acquisitions, lower financial investments, wide spatial coverage, high sampling density and noninvasive procedure [13]. Besides these technical aspects, new processing data and accessible technologies developed all around the world have contributing to an increasing insertion of geophysics in a great number of studies, including the environmental ones [14-16]. The constant transformations of global society and changes in the lands' use and occupation have required tools that contribute to the environmental impacts' management and the rehabilitation of natural resources, like in old mining areas [17-19].

The use of geophysical tools in environmental liabilities, however, is still poorly widespread compared to their potential to comprehend underground processes. One of the most important examples is hydrogeological dynamics studies within waste rock piles. There are countless studies that deal with aquifers' identification and characterization in different geological contexts [20-23], but few of them aim to understand the processes related to artificial aquifers built from human activities and that often represent a risk for an entire regional hydrological system. Considering this scenario, this paper seeks to understand the hydrogeological and structural dynamics in a waste rock pile of an old uranium mining, whose artificial aquifer system works as acid mine drainage source and, hence, could endanger the entire chemical and geological balance of its region.

\subsection{Study area and operational history}

The study area is part of the Osamu Utsumi uranium mine, a mining complex located at Poços de Caldas, southern region of Minas Gerais State (Fig. 1). Since the 90's, this mining complex faces a formal decommissioning process with serious concerns about the management of AMD contamination sites, including waste rock piles and the deactivated open-pit mine. These waste rock piles have a similar hydraulic behavior to those observed for artificial porous aquifer systems. Besides, they were disposed at the top of a fractured regional aquifer composed by the igneous rocks from the massif basement.

The Osamu Utsumi mine is part of the south region of the Poços de Caldas Plateau, a site with natural occurrences of radioactive minerals also known as Campo do Cercado [24]. At first, this location was administrated by a government company called Nuclebrás and became the very first active uranium mine in Brazil. A few years later, the INB - Indústrias Nucleares do Brasil-took control of the mining complex, which persists until today [25]. Its mining and exploration activities lasted from 1982 to 1995 and, since then, the mining industry faces a decommissioning process.

The mine is placed at the geological context of the Poços de Caldas Alkaline Complex (PCAC), a semicircular structure with a $35 \mathrm{~km}$ diameter and an area of $800 \mathrm{~km}^{2}$, listed as one of the largest alkaline complexes of the world [26]. The PCAC, located close to Minas Gerais and São Paulo States boundaries, is the result of successive alkaline rocks intrusions and subsequent hydrothermal alteration processes [27-29].

The Campo do Cercado ore reserve corresponds to approximately 17,200 tons of $\mathrm{U}_{3} \mathrm{O}_{8}$. In 1977 , the exploration operations started with the mobilization of approximately 5 million $\mathrm{m}^{3}$ of material, including soil and waste rocks. Therefore, the operational process was divided into three different sectors: mining exploration and physical and chemical processing [25]. The cutoff grade was established in $170 \mathrm{ppm}$ of soluble uranium. Based on this rate, the overburden and waste rocks generated by the uranium 


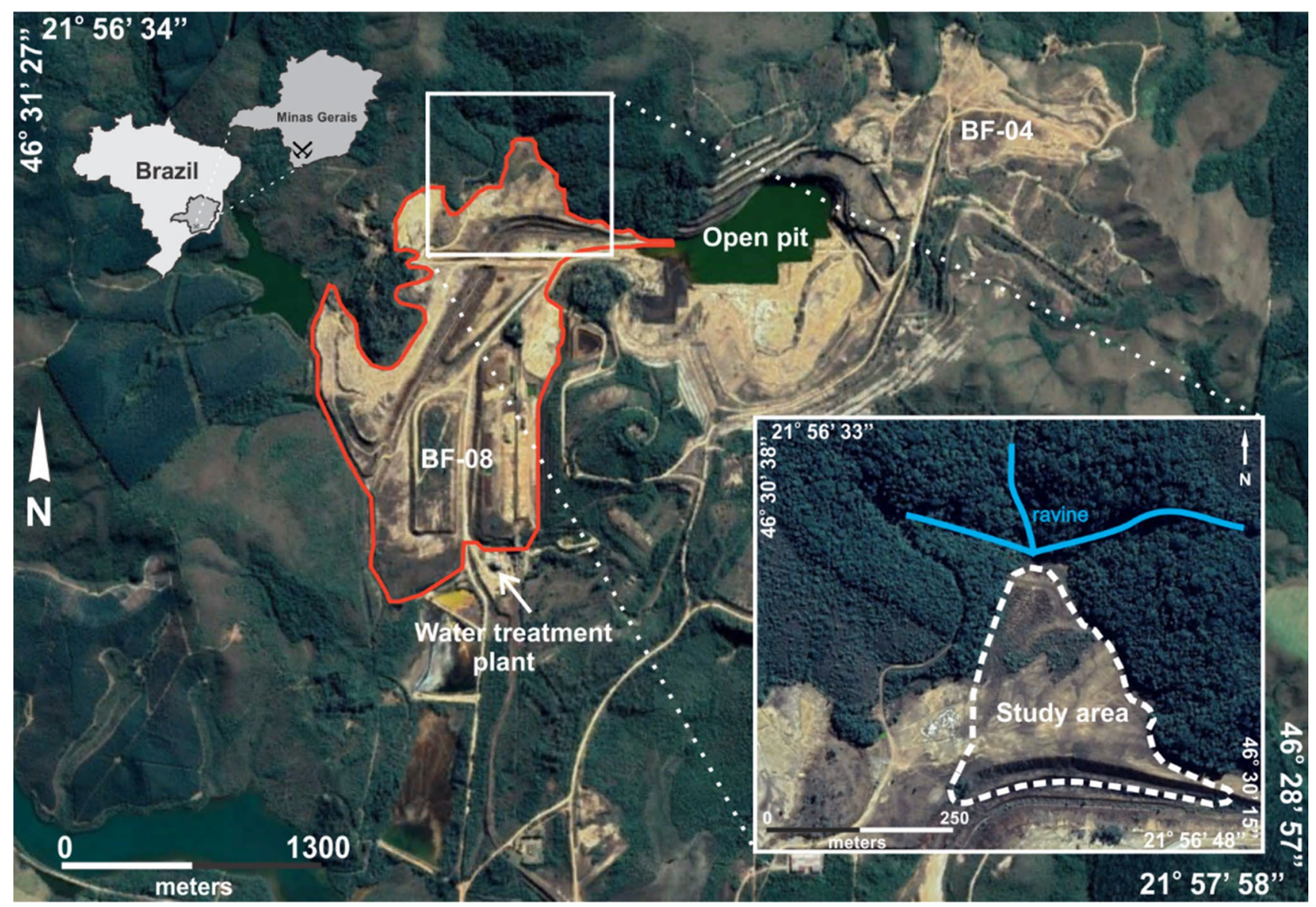

Fig. 1 Study area and delimitation of the waste rock pile known as BF-08

mining, with grade lower than $170 \mathrm{ppm}$, were sent to the local waste rock piles [20].

The study area is part of the waste rock pile called BF-8, which is composed essentially by phonolites and tinguaites [25]. This waste rock pile is located at the northwest portion of the mining complex and covers an area of 64.4 ha, with a volume of 14.8 million $\mathrm{m}^{3}$ of waste material [30]. This local comprehends an old valley which was covered by mining wastes and, eventually, is exposed to atmospheric precipitation. Those waters are channeled by a gully positioned at the northern limit of this structure. It is important to mention that, during the drought season, this system is permanently dry.

The end-dumping method had been chosen to build the $\mathrm{BF}-08$ pile, whose method provides a vast grain size variation without an appropriate control and compaction of the waste material [31]. In the same way, the study of [32] corroborates to the granulometric heterogeneity of the BF-08 pile. Moreover, this physical characteristic favors the occurrence of preferential flux paths inside the pile, besides the fact that the BF-8 was constructed through the deposition of the material on one of the slopes of the Cercado creek valley, whose waters flow to Antas River. In order to avoid infiltrations into the pile, an artificial channel was constructed for the mentioned creek.

Pyrite, the major mineral associated with AMD generation, occurs in the local ore as disseminated grains of approximately $8 \mathrm{~mm}$, comprising concentrations lower than $0.2 \%$. These parameters result an intermediate chemical reactivity [31].

The mining complex is installed in a region characterized by a temperate dry winter climate (Cwa/Cwb), with two well-defined seasons. The humid period occurs from November to March, whereas the months from April to October configure the driest season with the lowest temperatures, including occasional frosts. The mean annual precipitation is $1700 \mathrm{~mm}$, and $82 \%$ of all this rain is associated with the warmest period [33]. 


\section{Materials and methods}

The different materials that compose the local geological context can be distinguished from the contrast between their physical properties, whose parameters can be measured using indirect investigation methods, which include geophysical methods. Geophysical surveys are widely used and they are applied to a great number of scientific fields, as mineral prospection studies [34-36], petroleum geology [37-40], geotechnical engineering [41-43], and hydrogeological and environmental studies [44-46]. They are usually associated with conventional direct investigation methods, like monitoring wells, drillings, soil probing and trench [47-49].Considering all kinds of geophysical methods, the geoelectrical ones are the most valuable for environmental studies, especially the direct current (DC) resistivity method.

The DC resistivity method relies on the determination of the physical parameter of electrical resistivity $(\rho)$, whose intrinsic values are variable and related to each one of the different materials that compose the subsurface environment [50]. For hydrogeological studies, groundwater zones often provide a good contrast of resistivity values, which might be more accentuated depending on anomalous electrolyte concentrations (high electrical conductivity) related to leaching processes, including AMD [51-54].

The acquisition procedures comprehend the use of a tetrahedral metallic electrode set placed on the terrain surface. One electrode pair (AB) is responsible for the injection of electrical current into the ground, whereas the other two metallic terminals measure the potential difference $(E)$ between two spots on the surface. The geometric disposition of such components configures the type of geophysical array [55]. Moreover, deeper readings rely on the increase in distance between current electrodes, which makes possible multi-level investigations for stratigraphic characterization, saturated zone and contamination plumes.

For this study, performed during the driest season, seven acquisition lines were planned using electrical resistivity tomography (ERT) technique (Fig. 2). The majority of them were installed parallel to each other, covering an entire sector of the BF-08 pile, which includes an area of water spring. Theoretically, this factor should be a significant water source for the waste rock pile and an important component for the AMD generation. Regarding the geometric electrode disposition, the chosen geophysical array was the Wenner-Schlumberger type due to its denser grid readings and good vertical and horizontal resolutions. This system is based on the disposition of the $A B$ electrode pair in the extremities of the array, whereas the $C D$ potential pair constitutes the center of this collinear configuration and keeps a constant spacing through the development of the readings $[56,57]$. A spacing of $5 \mathrm{~m}$ was used between terminals.

The equipment used was an ABEM Terrameter LS resistivity meter with 84 channels and $250 \mathrm{~W}$ of power, which is calibrated for resistivity measurements through periodic cycles of electric current at low frequency, a procedure that allows filtering the acquired signal noise [58].

Res2Dinv (Geotomo Software) has been chosen as a data processing and inversion software, designed to interpolate and invert field data of electrical geophysical prospecting according to the mathematical model of ordinary least squares (OLS) [59]. This technique is responsible for smoothing the extreme values using a block modeling and, hence, reduces differences between the resistivity measured and the resistivity modeled. The quality of the adjustment is quantified by a standard deviation parameter called root mean squared (RMS) [59-61]. Besides, the topography parameter is also inserted in the model to prevent distortions on the resulting cross section.

Subsequently, the generation of 3D visualization models was made through the use of Oasis Montaj Platform (Geosoft), whose process of interpolation of the previous $2 \mathrm{D}$ geophysical products is based on the methods of kriging and minimum curvature, designed to guarantee the smoothing of the central values concerning the limits of the investigated area. The use of this kind of model, frequently applied in mineral prospection researches [62-64], makes possible a broad analysis of the hydrogeological conditions of the study area, including the identification of preferential groundwater pathways in the context of fractured and porous aquifer systems and delimitation of contamination plumes during the stages of characterization and monitoring of impacted sites [65-67].

\section{Results and discussion}

Inversion models produced from the geophysical data processing indicated a range of electrical resistivity values between 20 and $2000 \Omega \mathrm{m}$. The geophysical survey covered a depth of $70 \mathrm{~m}$ below the longest geophysical line, which allowed the identification of the boundary between the waste pile base and the top of the local rocky basement.

Resistivity values ranging from 20 to $80 \Omega \mathrm{m}$ indicate the presence of water with variable ions concentrations, which comprises the focus of this study. Values close to $20 \Omega \mathrm{m}$ are a sign of AMD-impacted waters, whereas resistivity values around $80 \Omega \mathrm{m}$ might be related to zones with lower salinity, at levels expected for natural waters. These resistivity values are compatible to those obtained 

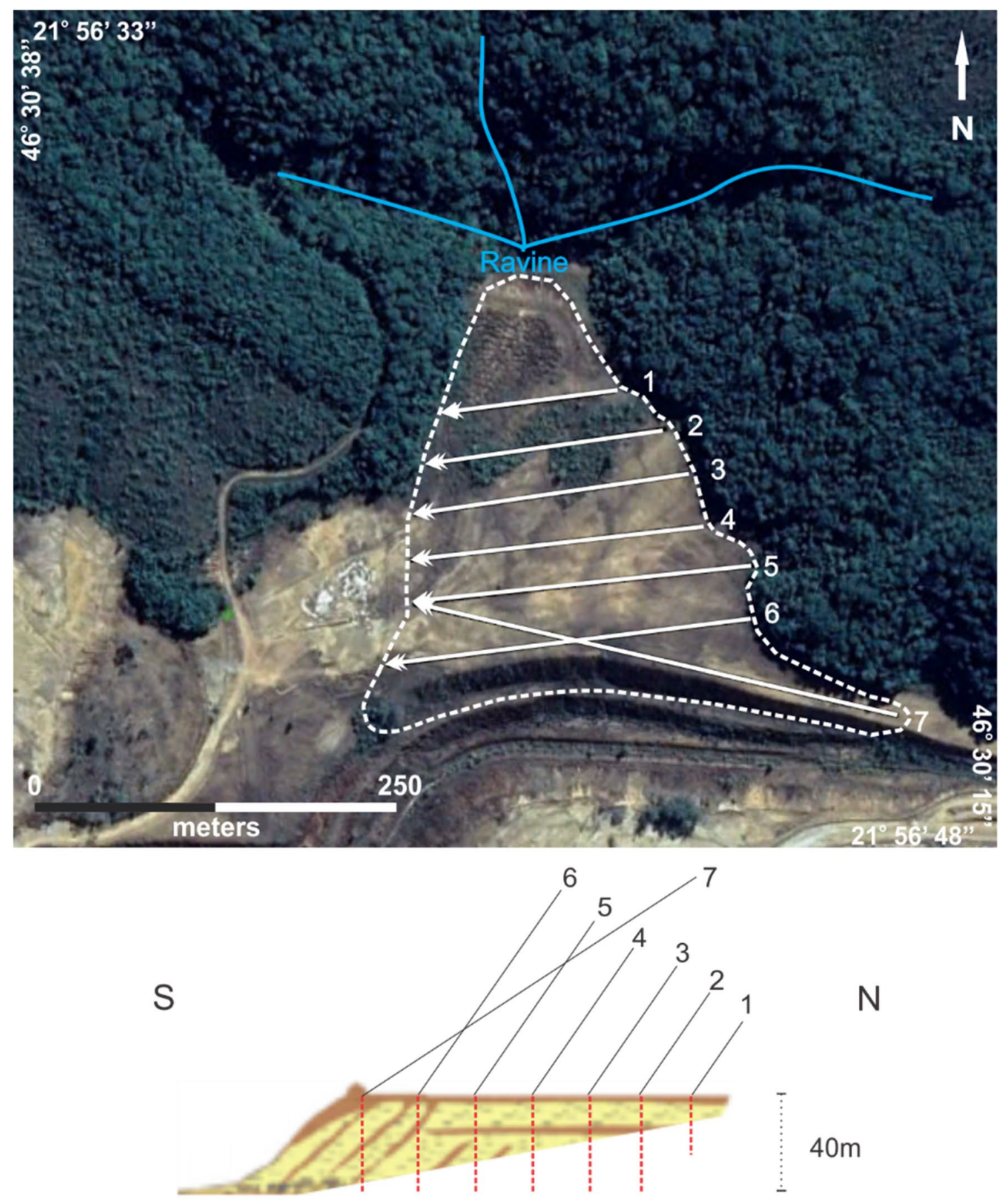

Predominance of course-grained material

Predominance of fine-grained material

Fig. 2 Disposal of geophysical lines along the superior level of BF-08

by $[46,65,67]$. Areas with resistivity values between 80 and $150 \Omega \mathrm{m}$ indicate streams associated with a natural or uncontaminated ground flow, in contrast with resistive anomalies (>150 $\Omega \mathrm{m}$ ) associated with the alkaline bedrock, with varying weathering degrees, and the waste rock material that composes the pile. It is important to notice that their moisture content decreases as the resistivity values increase.

The analysis of the inversion model related to the acquisition line 1 allowed the identification of two saturated 
Fig. 3 Resistivity inversion models of acquisition lines with the indication of the water accumulation zones and preferential underground fluxes. Lower values $(20 \Omega \mathrm{m})$ indicate saline waters (AMD)
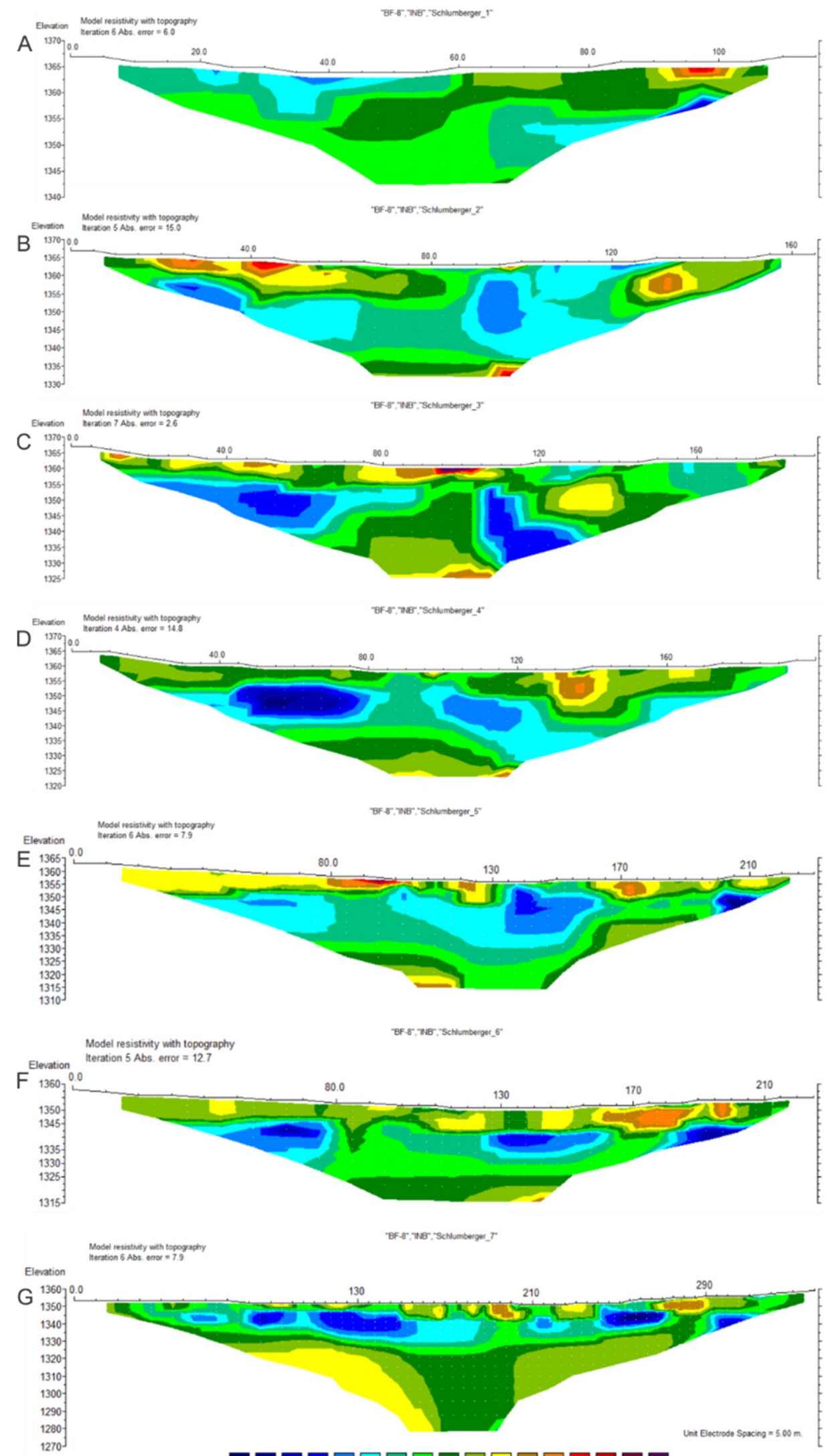

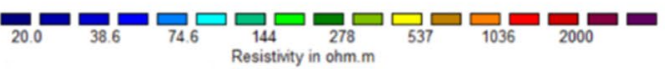


zones (Fig. 3a). The anomaly closer to the beginning of the line acquisition showed resistivity values around $75 \Omega \mathrm{m}$ at a maximum depth of $7.5 \mathrm{~m}$. Such shallow saturated zone might be related to a surface water concentration, originated from the local water spring. The contribution of meteoric water was also taken into account, especially due to the recent and previous rainy days at the region.

The second anomaly reaches at least $10 \mathrm{~m}$ in depth and configures lower resistivity values $(20 \Omega \mathrm{m})$, considered as an anomalous saline saturated zone as a result of the water-ore interaction. The water storage at shallow depths of the BF-08 might be explained by how the pile was built and its material arrangement, which promoted a certain degree of grain segregation. Thus, it is expected a lower hydraulic conductivity in the uppermost layers of the waste rock pile than compared to its base, generating preferential fluxes into the pile, whose occurrence, geometry and dynamics were confirmed by the two-dimensional visualization models obtained in this study.

According to the inversion model generated from acquisition line 2 , it is possible to observe a low resistivity anomaly that extends through the center of the section characterized by resistivity values ranging from 80 to $144 \Omega \mathrm{m}$ (Fig. 3b). This moderate saturation zone can be interpreted as a remaining preferential flux zone since the acquisitions were carried out during the dry season. In this way, the seasonal characteristic of the local water spring reflects directly the water volume that infiltrates into the BF-08 pile.

This geophysical section also made possible the understanding of the saturated zone associated with porous and fractured aquifer systems. The groundwater related to the BF-08 exhibits a horizontally elongated shape, limited by the pile-bedrock interface. However, values of $80 \Omega \mathrm{m}$ are present at the extremity of the inversion model as a vertical structure with continuity at deeper levels.

It was also possible to observe the existence of two accumulation zones into the moderate saturation portion showing low resistivity values ( $70 \Omega \mathrm{m}$ ). Those anomalies corroborate the hypothesis that, during the rainy season, the low saturation zone is more prominent, leading to a fusion of the accumulation zones due to the increase in their lateral extension and, as a result, the formation of preferential fluxes.

According to Sect. 3, the existence of two saturated zones is clear, both occurring at an initial depth of $10 \mathrm{~m}$ and characterized by resistivity values ranging from 40 to $65 \Omega \mathrm{m}$ (Fig. 3c). The anomaly $105 \mathrm{~m}$ distant from the origin represents a zone of high salinity (as already seen in the previous section) and vertically elongated shape with continuity at deeper levels, probably beyond the interface pile-bedrock. Thus, the groundwater propagates through zones of higher permeability. However, the exact waste rock pile-bedrock contact is difficult to delimitate due to the considerable heterogeneity of the waste material of the BF-08.

Another indicator of the existence of shallow saturated zones is the presence of vegetation exactly in the places intercepted by acquisition lines 1,2 and 3, as observed in Fig. 2, which corroborates with the related inversion models obtained.

Inversion model 4 presents similar characteristics described for Sects. 2 and 3 (Fig. 3d). The presence of the alkaline bedrock is clear, which is directly associated with the suspension of the groundwater above. This moderate saturation zone occurs in the central region of the section up to $7.5 \mathrm{~m}$ deep and shows two distinct accumulation zones, one of them defined by a vertical structure.

The configuration of the inversion model related to acquisition line 5 is also similar to the exposed in Sects. 2 and 3 (Fig. 3 e). The existence of a low saturated zone is clearly illustrated throughout the central area of the section, sustained by the bedrock, comprising minimal and maximum depths of $5 \mathrm{~m}$ and $30 \mathrm{~m}$, respectively. The thickness of the waste rock pile is significantly greater, especially at a distance of $125 \mathrm{~m}$ from the origin, where the topography of the old valley reaches its maximum depth.

These same characteristics are present in the acquisition line 6 , especially by the presence of a moderate saturated zone occurring in the central area of the inversion model, but in a segmented form (Fig. 3f).

There are three visible and well-defined accumulation zones inside the low saturation portion with horizontally aligned flattened forms. The first two anomalies comprise resistivity values varying from 25 to $40 \Omega \mathrm{m}$, occurring $40 \mathrm{~m}$ and $125 \mathrm{~m}$ from the origin point. The third structure is situated at a distance of $185 \mathrm{~m}$ and comprises values ranging from 20 to $40 \Omega \mathrm{m}$, which corresponds to higher salinity water in comparison with the other two zones. Furthermore, it is possible to distinguish the less fractured bedrock that regulates the suspension of the groundwater in the porous system above.

Finally, the inversion model 7 was generated by the longest acquisition line $(320 \mathrm{~m})$, resulting in a maximum reading depth of $80 \mathrm{~m}$. Its position differs from the other lines as it presents an oblique orientation. Once again, it is possible to identify the fractured bedrock, approximately at $25 \mathrm{~m}$ of depth (Fig. 3g).

As seen before, the moderate saturated zone comprises the entire extension of inversion model 7 , at an initial depth of $5 \mathrm{~m}$ and $15 \mathrm{~m}$ of thickness. In addition, two saline water accumulation zones were recognized inside this zone, according to the inversion model, without a connection with the fractured aquifer. The variation in the contour of the anomaly was understood as a result of the previous 
morphology of the old valley, which was filled up with the waste rock material during the construction of the BF-08.

The integration of inversion models through the interpolation process allowed the elaboration of pseudo-3D block models, as an attempt of recognition of preferential flux zones within the basement that sustains the BF-08. The analysis of such block models in the topographic level of $1333 \mathrm{~m}$ ( $42 \mathrm{~m}$ below the surface) reveals the existence of two low resistivity zones ( $>40 \Omega \mathrm{m}$ ) characterized by elongated shapes and orientation according to N350 direction. An evaluation of the interior of the 3D block allows the identification of the existence of two independent fracture

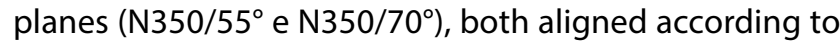
the central axis of the old fluvial valley (Fig. 4).

The structural analysis carried out in the abandoned open-pit mine by Targa et al. [46] revealed the existence of a complex system of fractures conditioning the water flux from the mining front to the mine pit base. The four fronts (NE, SE, SW and NW) contain a predominance of a set of fracture planes with dip direction toward the center of the mine, whose intersection configures a catchment area and results in the retention of waters in the base of the old pit. These waters are originated from the springs that occur on the rock massifs on the mining fronts (Fig. 5).
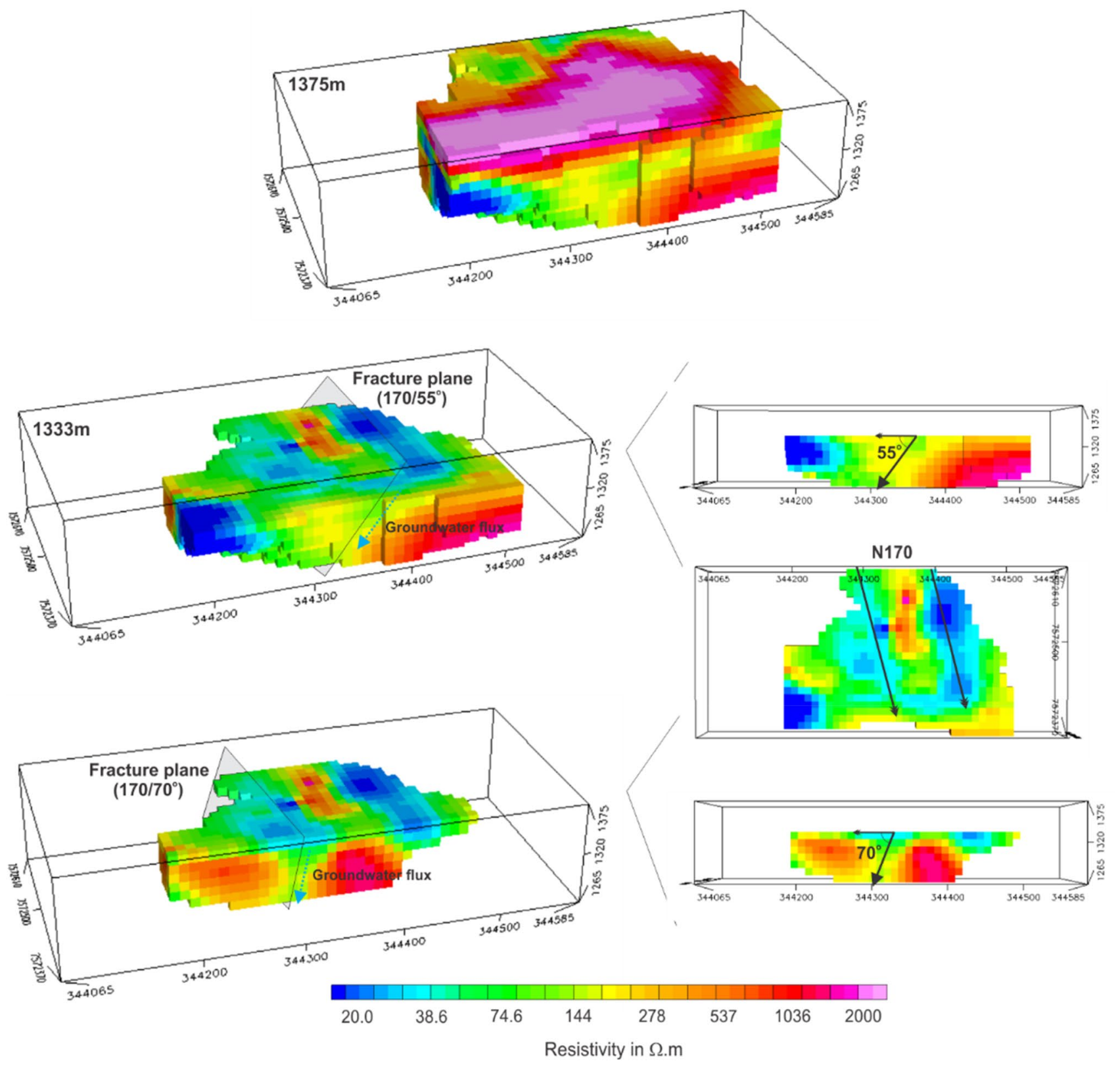

Fig. 4 Pseudo-3D resistivity models, with fractured plane of the groundwater flux 


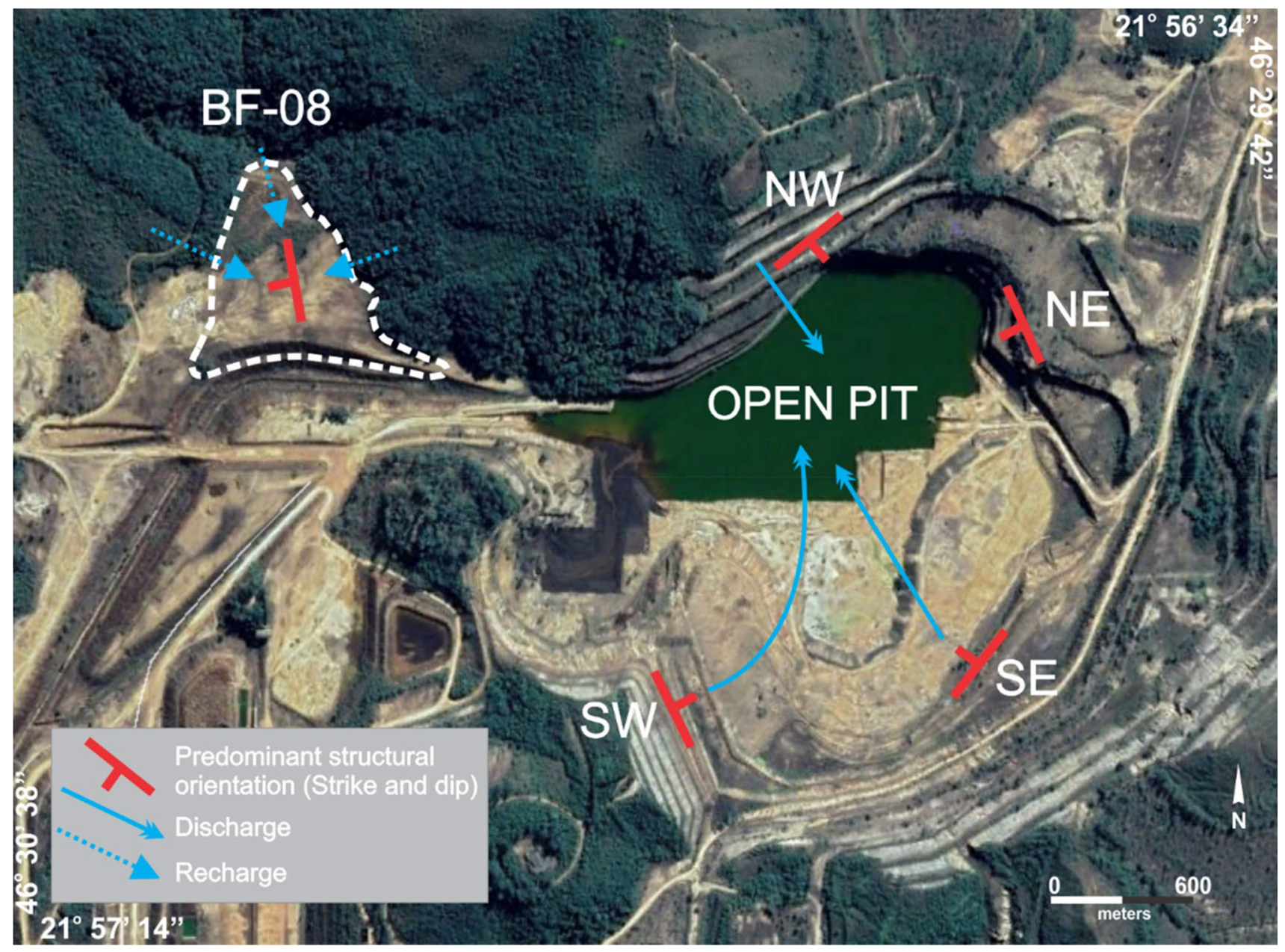

Fig. 5 Structural pattern of the open pit and BF-08

The NE front is the only sector with no indication of groundwater flux through fractures, predominantly oriented according to $\mathrm{N} 185 / 85^{\circ}$. Coincidently, the recognized structures in the basement of BF-08 present orientation very similar to those observed in NE front of the abandoned pit, whose preferential direction was characterized by $\mathrm{N} 170$ (Fig. 5).

The absence of pieces of evidence of water springs on both NE open-pit front and BF-08 front indicates that this system might contribute to the recharge of the underlying fractured aquifer through the infiltration of meteoric waters, whereas the other systems constitute flow pathways to the surface, i.e., zones of discharge as water springs.

It is relevant to mention that the mine pit was constructed in the area of the old water spring of the Cercado creek and, since the termination of mining activities, the waters inside the open pit are permanently pumped to a treatment plant for uranium neutralization and to avoid an overflow to the old creek channel. Both surface water-waste sulfide interaction and the oxidation of sulfides by the percolation of waters through fractures in the rock massif in the pit mine are responsible for the AMD generation.

\section{Conclusions}

The effectiveness of the DC resistivity method applied in the characterization of the major components of the BF-08 hydrogeological system was notorious, especially due to the electrical properties contrasts of the materials which made possible the distinction of AMD affected waters (bellow $40 \Omega \mathrm{m}$ ) from those natural non-polluted groundwater zones. Another important aspect relies on the discrimination of the local porous and fractured systems, whose correlations allowed the identification of preferential fluxes and accumulation zones within the waste rock pile.

The results reflect the hydrogeological complexity of areas impacted by mining activities, especially due to the 
negative effects of the hydrological dynamics caused by the modification of natural terrain topography. In the case of Osamu Utsumi uranium mine, the construction of the waste rock pile in a fluvial valley caused huge impacts, whose negative effects were visible in the geophysical products.

BF-08 pile is considered a heterogeneous artificial porous aquifer system conditioned by high spatial variability of grain sizes, lithology and compaction. These factors are directly related to the generation of regions of preferential groundwater fluxes within the waste rock pile. Also, the existing underlying fractured aquifer system is associated with the existence of sub-vertical groundwater fluxes conditioned by fractures in the bedrock. Thus, this feature was understood as water contribution from the porous to the fractured aquifer system.

The existence of such saturated portions within the waste rock pile as permanent features provides sulfide minerals oxidation during the entire hydrological cycle. Likewise, the pyrite present in the waste rock material is a permanent factor of AMD generation, which will last for many decades, especially due to the presence of nearby water springs and lack of waterproofing components on the top of the pile.

The finding of distinct structural patterns in terms of water flux in the crystalline basement configures a fundamental step in the planning of actions of restraint and treatment of AMD. The effluent generated by water-sulfide interaction in the fracture systems of the SE, SW and NW pit fronts configures surface springs and fluxes toward the lower levels of the terrain, locally represented by the base of the open-pit mine. The current AMD remediation system consists of the lowering of the water level in the abandoned pit and treatment of such effluent. Subsequently, the treated water is returned to the local catchment basin.

However, the finding of a fracture system responsible for the recharge of the basement aquifer system represents an infiltration pathway for both meteoric water and AMD. This scenario indicates the existence of a previously ignored alternative AMD propagation pathway, which must be comprehended in more detail for eventual pumping and treatment actions.

Acknowledgements The authors are thankful to São Paulo Research Foundation (FAPESP) for the financial support whereby Process Number 2018/14565-3 (Regular Project), the Applied Geology Department of UNESP-Rio Claro for the availability of the geophysical equipment and the Brazilian Nuclear Industries (Indústrias Nucleares do Brasil - INB) for the provided access to the study area.

\section{Compliance with ethical standards}

Conflict of interest On behalf of all authors, the corresponding author states that there is no conflict of interest.

\section{References}

1. Tilman D, Cassman KG, Matson PA, Naylor R, Polasky S (2002) Agricultural sustainability and intensive production practices. Nature 418(6898):671-677. https://doi.org/10.1038/natur e01014

2. Frind EO, Molson JW, Rudolph DL (2006) Well vulnerability: a quantitative approach for source water protection. Groundwater 44(5):732-742. https://doi.org/10.111 $1 / j .1745-6584.2006 .00230 . x$

3. Veiga LBE, Magrini A (2013) The Brazilian water resources management policy: fifteen years of success and challenges. Water Resources Manag 27(7):2287-2302. https://doi.org/10.1007/ s11269-013-0288-1

4. Younger PL, Wolkersdorfer C (2004) Mining impacts on the freshwater environment: technical and managerial guidelines for catchment scale management. Mine Water Environ 23:s2. https://doi.org/10.1007/s10230-004-0028-0

5. Abdelouas A (2006) Uranium mill tailings: geochemistry, mineralogy, and environmental impact. Elements 2:335-341. https://doi.org/10.2113/gselements.2.6.335

6. Blowes D (1997) The environmental effects of mine wastes. In: Proceedings of exploration 97: fourth decennial international conference on mineral exploration, vol 4. Prospectors and Developers Association, Toronto, pp 887-892

7. Pastore EL, Mioto JA (2000) Impactos ambientais em mineração com ênfase à Drenagem Ácida Mineira e transporte de contaminantes. Rev Solos Rochas 23(1):33-56

8. Campaner VP, Silva WL (2009) Processos físico-químicos em drenagem ácida de mina em mineração de carvão. Quím Nova 32(1):146-152

9. Tiwary RK, Dhar B (1994) Environmental pollution from coal mining activities in Damodar river basin, India. Mine Water Environ 13(June-December):1-10

10. Akcil A, Koldas S (2006) Acid mine drainage (AMD): causes, treatment and case studies. J Clean Prod 14(12):1139-1145. https://doi.org/10.1016/j.jclepro.2004.09.006

11. Hakkou R, Benzaazoua M, Bussiere B (2008) Acid mine drainage at the abandoned Kettara mine (Morocco): 1. Environmental characterization. Mine Water Environ 27(3):145-159. https ://doi.org/10.1007/s10230-008-0036-6

12. Kleinmann RLP, Crerar DA, Pacelli RR (1981) Biogeochemistry of acid mine drainage and a method to control acid formation. Min Eng (NY, US) 33:3

13. Reynolds JM (2011) An introduction to applied and environmental geophysics. Wiley, NewYork

14. Pazzi V, Tapete D, Cappuccini L, Fanti R (2016) Na electric and electromagnetic geophysical approach for subsurface investigation of anthropogenic mounds in an urban environment. Geomorphology 273:335-347. https://doi.org/10.1016/j. geomorph.2016.07.035

15. Cavallo G, Benedetto D, An Castrignanò, Quarto R, Vonella AV, Buttafuoco G (2016) Use of geophysical data for assessing 3D soil variation in a durum wheat field and their association with crop yield. Biosyst Eng. https://doi.org/10.1016/j.biosystems eng.2016.07.002

16. Khazri D, Gabtni H (2018) Geophysical methods integration for deep aquifer reservoir characterization and modeling (Sidi Bouzid basin, central Tunisia). J Afr Earth Sci 138:289-308. https://doi.org/10.1016/j.jafrearsci.2017.11.024

17. Ramalho E, Carvalho J, Barbosa S, Santos FAM (2009) Using geophysical methods to characterize an abandoned uranium mining site, Portugal. J Appl Geophys 67:14-33. https://doi. org/10.1016/j.jappgeo.2008.08.010 
18. Gáldon JM, Rey J, Martínez J, Hidalgo MC (2017) Application of geophysical prospecting techniques to evaluate geologicalmining heritage: the Sinapismo mine (La Carolina, Southern Spain). Eng Geol 218:152-161. https://doi.org/10.1016/j. enggeo.2017.01.012

19. Lechner AM, Mclntyre N, Witt K, Raymond CM, Arnold S, Scott M, Rifkin W (2017) Challenges of integrated modelling in mining regions to address social, environmental and economic impacts. Environ Model Softw 93:268-281. https://doi. org/10.1016/j.envsoft.2017.03.020

20. Song SH, Song YM, Kwon BD (2004) Application of hydrogeological and geophysical methods to delineate leakage pathways in an earth fill dam. Expl Geophys 36(1):73-77. https:// doi.org/10.1071/EG05092

21. Falgàs $E$, Ledo J, Benjumea $B$, Queralt $P$, Marcuello $A$, Teixidó $T$, Martí A (2011) Integrating hydrogeological and geophysical methods for the characterization of a deltaic aquifer system. Surv Geophys 32:857-873. https://doi.org/10.1007/s1071 2-011-9126-2

22. Himi M, Tapias J, Benabdelouahab S, Salhi A, Rivero L, Elgettafi M, Mandour AE, Stitou J, Casas A (2016) Geophysical characterization of saltwater intrusion in a coastal aquifer: the case of Martil-Alila plain (North Morocco). J Afr Earth Sci 126:136147. https://doi.org/10.1016/j.jafrearsci.2016.11.011

23. Day-Lewis FD, Slater LD, Robinson J, Johnson CD, Terry N, Werkema D (2017) An overview of geophysical technologies appropriate for characterization and monitoring at fractured-rock sites. J Environ Manag 204:709-720. https://doi. org/10.1016/j.jenvman.2017.04.033

24. Schorscher HD, Shea ME (1992) The regional geology of the Poços de Caldas alkaline complex: mineralogy and geochemistry of selected nepheline syenites and phonolites. J Geochem Explor 45:25-51. https://doi.org/10.1016/03756742(92)90121-N

25. Souza AM, Silveira CS, Pereira RM (2013) Contribuições dos metais provenientes das pilhas de rejeito da Mina Osamu Utsumi a drenagens do Complexo Alcalino de Poços de Caldas, Minas Gerais. Geochim Bras 27(1):63-76

26. Thedeschi MF, Vieira PLNCR, Nomo TA (2015) Projeto fronteiras de Minas Gerais: Folha Caldas/Poços de Caldas, escala 1:100.000. Universidade Federal de Minas Gerais

27. Fraenkel MO, Santos RC, Loureiro, FEVL, Muniz WS (1985) Jazida de urânio no Planalto de Poços de Caldas-Minas Gerais. Principais depósitos minerais do Brasil, v. 1, Recursos Minerais Energéticos, MME, DNPM e CVRD, Brasília, pp 89-103

28. Shea ME (1991) Isotopic geochemical characterization of selected nepheline syenites and phonolites from the Poços de Caldas alkaline complex, Minas Gerais, Brazil. Poços de Caldas Report n 4. In: NAGRA, SKB, UK DOE. Poços de Caldas Project

29. Ulbrich HH, Vlach R, Ulbrich MN, Kawashita K (2002) Penecontemporaneous syenitic-phonolitic and basic-ultrabasiccarbonatitic rocks at the Poços de Caldas Alkaline Massif, SE Brazil: geologic and geochronologic evidence. Rev Bras Geociênc 32(1):15-26

30. Cipriani M (2002) Mitigação dos impactos sociais e ambientais decorrentes do fechamento definitivo de minas de urânio. Thesis. Universidade Estadual de Campinas, Campinas

31. Souza VP (1995) Drenagens ácidas do estéril piritoso da mina de urânio de Poços de Caldas: Interpretação e implicações ambientais. Escola Politécnica, USP, São Paulo

32. Murta FC (2006) Ensaios de colunas para a avaliação de remediação passiva de drenagem ácida na mina Osamu Utsumi (INB), Caldas/MG

33. Holmes DC, Pitty AE, Noy DJ (1992) Geomorphological and hydrogeological features of the Poços de Caldas caldera analogue study sites. J Geochem Expl 45:215-247. https:// doi.org/10.1016/0375-6742(92)90126-S

34. Elkattan EM, Sadek HS, Rabie SI, Hassanein HI (1996) Ground geophysical study for development and exploration of El Missikat radioactive minerals prospect, central Eastern Desert of Egypt. Int J Rock Mech Min Sci Geomech Abstr 33:A264. https ://doi.org/10.1016/0969-8086(95)00006-D

35. Gómez-Ortiza D, Fernández-Remolar DC, Granda A, Quesada C, Granda T, Prieto-Ballesteros O, Molina A, Amils R (2014) Identification of the subsurface sulfide bodies responsible for acidity in Río Tinto source water, Spain. Earth Planet Sci Lett 391:36-41. https://doi.org/10.1016/j.epsl.2014.01.022

36. Guo Z, Xue G, Liu J, Wu X (2020) Electromagnetic methods for mineral exploration in China: a review. Ore Geol Rev. https://doi. org/10.1016/j.oregeorev.2020.103357

37. Bukaty MB (2009) Groundwater geology of the western Siberian craton (implications for petroleum exploration). Russ Geol Geophys 50(11):930-942

38. Marinenko AV, Epov MI (2017) Subsurface geoelectric array with two transmitters for petroleum exploration in offshore areas. Russ Geol Geophys 58(10):1263-1269. https://doi.org/10.1016/j. rgg.2016.12.011

39. Afanasenkov AP, Yakovlev DV (2018) Application of electrical prospecting methods to petroleum exploration on the northern margin of the Siberian Platform. Russ Geol Geophys 59(7):827845. https://doi.org/10.1016/j.rgg.2018.07.008

40. Ayoubi S, Samadi MJ, Khademi H, Shirvani M, Gyasi-Agyei Y (2020) Using magnetic susceptibility for predicting hydrocarbon pollution levels in a petroleum refinery compound in Isfagan Province, Iran. J Appl Geophys. https://doi.org/10.1016/j.jappg eo.2019.103906

41. Crawford MM, Bryson LS, Woolery EW, Wang Z (2018) Using 2-D electrical resistivity imaging for joint geophysical and geotechnical characterization of shallow landslides. J Appl Geophys 157:37-46. https://doi.org/10.1016/j.jappgeo.2018.06.009

42. Bortolozo CA, Motta MFB, Andrade MRM, Lavalle LVA, Mendes RM, Simões SJC, Mendes TSG, Pampuch LA (2019) Combined analysis of electrical and electromagnetic methods with geotechnical soundings and soil characterization as applied to a landslide study in Campos do Jordão City, Brazil. J Appl Geophys 161:1-14. https://doi.org/10.1016/j.jappgeo.2018.11.017

43. Dezert T, Lopes SP, Fargier Y, Côte P (2019) Combination of geophysical and geotechnical data belief functions: assessment with numerical and laboratory data. J Appl Geophys. https:// doi.org/10.1016/j.jappgeo.2019.103824

44. Poisson J, Chouteau M, Aubertin M, Campos D (2009) Geophysical experiments to image the shallow internal structure and the moisture distribution of a mine waste rock pile. J Appl Geophys 67(2):179-192. https://doi.org/10.1016/j.jappgeo.2008.10.011

45. Maurya PK, Rønde VK, Fiandaca G, Balbarini N, Aukena E, Bjerg PL, Christiansen AV (2017) Detailed landfill leachate plume mapping using $2 \mathrm{D}$ and $3 \mathrm{D}$ electrical resistivity tomography - with correlation to ionic strength measured in screens. J Appl Geophys 138:1-8. https://doi.org/10.1016/j.jappgeo.2017.01.019

46. Targa DA, Moreira CA, Camarero PL, Casagrande MFS, Alberti HL (2019) Structural analysis and geophysical survey for hydrogeological diagnosis in uranium mine, Poços de Caldas (Brazil). SN Appl Sci 1:1-12. https://doi.org/10.1007/s42452-019-0309-7

47. Benson AK, Payne K, Stubben MA (1997) Mapping groundwater contamination using dc resistivity and VLF geophysical methods-a case study. Geophysics 62(1):80-86. https://doi. org/10.1190/1.1444148

48. Rucker DF, Levitt MT, Greenwood WJ (2009) Three-dimensional electrical resistivity model of a nuclear waste disposal site. J Appl Geophys 69(3-4):150-164. https://doi.org/10.1016/j.jappg eo.2009.09.001 
49. Shokri BJ, Ramazi H, Ardejani FD, Moradzadeh A (2014) Integrated time-lapse geoelectrical-geochemical investigation at a reactive coal washing waste Pile in Northeastern Iran. Mine Water Environ 33(3):256-265. https://doi.org/10.1007/s1023 0-014-0265-9

50. Kearey P, Brooks M, Hill I (2002) An introduction to geophysical exploration. Blackwell Science, Oxford

51. Merkel RH (1972) The use of resistivity to delineate acid mine drainage in ground water. Ground Water 10(5):38-42. https:// doi.org/10.1111/j.1745-6584.1972.tb03590.x

52. Campbell DL, Fitterman DV (2000) Geoelectrical methods for investigating mine dumps. In: Fifth international conference on acid rock drainage. ICARD, Denver

53. Power C, Tsourlos P, Ramasamy M, Nivorlis A, Mkandawire $M$ (2018) Combined DC resistivity and induced polarization (DC-IP) for mapping the internal composition of a mine waste rock pile in Nova Scotia, Canada. J Appl Geophys 150:40-51. https://doi. org/10.1016/j.jappgeo.2018.01.009

54. Casagrande MFS, Moreira CA, Targa DA, Alberti HLC (2018) Integration of geophysical methods in the study of acid drainage in uranium mining waste. Rev Bras Geofís 36(4):1-12. https://doi. org/10.22564/rbgf.v36i4.1968

55. Everett ME (2013) Near-surface applied geophysics. Cambridge University Press, Cambridge, $\mathrm{p} 441 \mathrm{p}$

56. Milson J (2003) Field geophysics. Wiley, England, p 232

57. Knodel K, Lange G, Voift HJ (2007) Environmental geology - Handbook of field methods and case studies. Springer, Germany, p 1357

58. ABEM (2012) Terrameter LS-instruction manual. ABEM Instrument $A B$, Sundbyberg, $p 122$

59. Loke MH, Baker RD (1996) Rapid least-squares inversion of apparent resistivity pseudosections by quasi-Newton method. Geophys Prospect 44:131-152. https://doi. org/10.1111/j.1365-2478.1996.tb00142.x

60. Loke MH (2010) Practical guide 2-D and 3-D surveys. In: Electrical imaging surveys for environmental and engineering
61. Bania G, Cwiklik M (2013) 2D Electrical resistivity tomography interpretation ambiguity-example of field studies supported with analogue and numerical modelling. Geol Geophys Environ 39(4):331-339. https://doi.org/10.7494/geol.2013.39.4.331

62. Aizebeokhai AP, Olayinka Al, Singh VS, Uhuegbu CC (2011) Effectiveness of 3D geoelectrical resistivity imaging using parallel 2D profiles. Curr Sci 101(8):1036-1052

63. Moreira CA, Helene LPI, Nogara P, Ilha LM (2018) Analysis of leaks from geomembrane in a sanitary landfill through models of electrical resistivity tomography in South Brazil. Environ Earth Sci 77(7):1-11. https://doi.org/10.1007/s12665-017-7180-x

64. Cortês ARP, Moreira CA, Paes RAS, Veloso DIK (2019) Geophysical and metalogenetic modelling of the copper occurrence in Camaquã Sedimentary Basin, Brazilian Southern. Pure appl Geophys 176:4955-4968. https://doi.org/10.1007/s00024-01902190-8

65. Veloso DIK, Moreira CA, Côrtez ARP (2015) Integration of geoelectrical methods in the diagnostic of a diesel contaminated site in Santa Ernestina (SP, Brazil). Rev Bras Geofís 33(4):667-676. https://doi.org/10.22564/rbgf.v33i4.760

66. Casagrande MFS, Moreira CA, Targa DA (2019) Study of generation and underground flow of acid mine drainage in waste rock pile in an uranium mine using electrical resistivity tomography. Pure appl Geophys 177:1-19. https://doi.org/10.1007/s0002 4-019-02351-9

67. Moreira CA, Paes RAS, Ilha LM, Bittencourt JC (2018) Reassessment of copper mineral occurrence through electrical tomography and pseudo 3D Modeling in Camaquã Sedimentary Basin, Southern Brazil. Pure appl Geophys 176:37-750. https://doi. org/10.1007/s00024-018-2019-2

Publisher's Note Springer Nature remains neutral with regard to jurisdictional claims in published maps and institutional affiliations. 